\title{
Privatisation or re - nationalisation in Russia? - Strengthening strategic government policies within the economy ${ }^{*}$
}

\author{
Peeter Vahtra, Kari Liuhto, Harri Lorentz ${ }^{* *}$
}

Recent years have witnessed increasing state involvement in the Russian enterprise sector, which has been met with contradictory reactions from investors. In the current article, we discuss the development of privatisation and corporate governance in Russia in comparison to other CIS. We provide three company cases with subsequent discussion on ownership, control, and corporate governance in Russia, given the increasing state leverage in the country's industrial sector. Aimed at facilitating discussion among policy makers, investors, and academics alike, we finally offer an insight into strategic dimensions of the Russian enterprise sector by developing a matrix of strategic government policies within the Russian industry.

In den letzten Jahren konnte ein stärkeres Agieren des Staates im russischen Unternehmenssektor beobachtet werden, das auf ein geteiltes Echo von Seiten der Investoren stiess. In diesem Artikel diskutieren wir die Entwicklung der Privatisierung und der Corporate Governance in Russland im Vergleich zu anderen GUS-Staaten. Wir diskutieren drei Unternehmens-Fallstudien bezüglich Eigentümerschaft, Kontrolle und Corporate Governance in Russland, vor dem Hintergrund des steigenden staatlichen Einflusses im Industriesektor des Landes. Um eine Diskussion unter Politikern, Investoren und Wissenschaftlern zu erleichtern, bieten wir schliesslich einen Einblick in die strategischen Dimensionen des russischen Unternehmenssektors durch die Entwicklung einer Matrix von strategischen Regierungsverordnungen.

Key words: Russia, corporate governance, ownership, foreign investments

* Manuscript received: 25.04.06, accepted: 08.11.06 (1 revision)

** Peeter Vahtra, Researcher, Pan-European Institute, Turku School of Economics, Finland. Main research areas: Internationalisation and foreigh direct investments by Russian companies, Russian Economic policy and Russian energy sector. Corresponding address: Peeter.Vahtra@tse.fi.

Kari Liuhto, Prof./Director, Pan-European Institute, Turku School of Economics, Finland. Main research areas: Russian inward and ourward foreign direct investment, EU-Russian economic relation and the EU's Northern Dimension, the Baltic Sea economic region.

Harri Lorentz, Senior Research Associate, Turku School of Economics, Finland. Main reseach areas: Industrial restructuring in Russia, Supply chain management and the Russian distribution system. 


\section{Introduction}

During the 1990s, the former socialist countries of the Commonwealth of Independent States (CIS) have taken considerable steps towards privatising their enterprise sectors to rebuild their industrial competitiveness through more efficient enterprise management and governance. At divergent levels, the restructuring has facilitated an economic upturn across the CIS, as the private enterprise sectors are gradually catching up with Western corporate governance.

Within the CIS, Russia has been the leading country in terms of their share of the private sector in a country's economy from the very beginning of the transition period. During recent years we have, however, witnessed reversed development in privatisation in Russia. Initiated by the re-nationalisation of some of Russia's most prominent oil assets, the state is evidently regaining control over the country's strategic industrial sectors.

The strengthening of state ownership through the reformation of state holding companies and the introduction of hybrid forms of private and public governance has, in many instances, come at the price of destabilising the credibility of the Russian institutional and legal environment. On the other hand, the recent developments have so far done little to undermine investor confidence in the Russian economy; as indicated by several examples from the past year, increased governmental support through strengthened control and ownership in many Russian companies has been one of the major drivers of the stocks of the companies involved, on both domestic and international exchanges.

In the current article, we discuss the development of privatisation and corporate governance in Russia in comparison to other CIS, with a subsequent presentation of related Russian company cases and discussion on ownership, control, and corporate governance in Russia, given the increasing state leverage in the country's industrial sector. While extensive international critique has been posted on the subject of the re-nationalisation of Russian industrial assets, we attempt to provide constructive discussion on the pros and cons of the increasing role of the state in the Russian economy. Aimed at facilitating discussion among policy makers, investors, and academics alike, we offer an insight into strategic dimensions of the Russian enterprise sector with regard to increasing state control over Russian industrial assets and its implications for foreign investments in Russia.

\section{Literature review of ownership, control and corporate governance in Russia}

In recent years, a number of scholars have studied the issues of ownership and control in the Russian enterprise population, and particularly in the major industrial corporations. For example, the management transformation of the Soviet enterprise, and the consequent implementation of new productivity 
criteria in Russia and the CIS, has been examined by Liuhto (1999a; 1999b). Enterprise history in terms of state involvement was found to be a significant predictor of performance.

Generally, the studies on ownership, control, and the development of corporate governance in Russian industry generally suggest high levels of ownership concentration on one hand, and the superior performance and governance practices of private companies over the state-owned ones, on the other (Murav'ev 2003; Guriev/Rachinsky 2004). While both the agency and stakeholder theories have gained some support towards explaining the development of corporate governance in Russia, scholars have further recognised the possibility of Russia developing its own distinctive model of corporate governance, based on the conditions of its unique institutional environment (Puffer/McCarty 2003).

In particular, the effects of ownership concentration on corporate governance have drawn the interest of scholars. Guriev and Rachinsky (2004) stress the high level of ownership concentration in Russia, with the 23 largest business groups controlling more than a third of the sales in their sample representing the Russian industrial field. Guriev et al. (2004) conclude that the concentration of enterprise shares in the hands of a large shareholder has, up to a certain level, a positive impact on corporate governance. However, when too large a block of shares is consolidated by a large external shareholder, the effects of any further increase in their shareholding on corporate governance were found to be of a negative nature.

Earlier research has additionally focused on state shareholdings in Russia due to the continuously high share of state ownership in the Russian industry. The results generally suggest a lower quality of corporate governance in the stateowned companies. In their study, Kuznetsova and Kuznetsov (1999) pointed out the inability of the state to act as a responsible shareholder and to utilise its power for the benefit of the firms in which it had shares.

According to Guriev and Rachinsky (2004), both private enterprises controlled by minority shareholders and large external owners outperformed state-owned companies in Russia. Similarly, Murav'ev (2003) concluded that the performance of the companies with state ownership was significantly worse than that of privately-controlled enterprises. As opposed to the common misconception that only low quality assets were left under state control, Murav'ev (2003) found the reasons for poor performance of state-owned companies are weak control over the companies and inadequate monitoring of managers. In a related study on the mechanisms of state ownership in the enterprise sector, Kuznetsov and Murav'ev (2001) found management through a state holding company to be preferable to direct government control. 
On average, the researchers have found the quality of corporate governance to be higher in large enterprises having lower unit costs of introducing corporate governance standards (Guriev et al. 2004). Similarly, McCarthy and Puffer (2003) cite that small Russian companies seldom have the resources to attract significant foreign investments and seek listing on stock exchanges, thus, lack any major incentives for developing corporate governance. Corporate governance has been found to be an important factor in restructuring privatised companies in all transition economies, improving relations among shareholders, directors, and managers (Filatotchev et al. 2003; Shekshnia 2004). Due to the aforementioned reasons, large companies have been at the forefront of this development, being the first to become involved in corporate governance issues (McCarthy/Puffer 2003). In addition, Black (2001) concluded that the quality of corporate governance is highly positively correlated with the market value of large Russian enterprises listed on domestic and foreign stock exchanges. Since the number of the latter has considerably increased in recent years, we can expect the impact of good corporate governance to have diminished somewhat, but likely to remain significant.

To conclude, earlier literature indicates a relatively modest implementation of corporate governance practices in Russia. Additionally, the researchers have found state ownership to have a profound impact on enterprise performance and corporate governance. In our current article, we focus on both issues by providing insights into recent developments of industrial ownership in Russia.

\section{Data collection}

The data for the current article are derived from a systematic follow-up process on Russian enterprise sector, initiated by the authors in 1999. We base our findings on a database compiled in the context of a larger research project. In compiling the database, an extensive set of company reports, central banks' and statistical offices' reports, business intelligence services, numerous business reviews, and internet sources have been consulted. The data has been derived from both Russian and other sources, with a particular emphasis on balancing differing viewpoints. An extensive coverage of secondary data has been viewed by the authors as the most trustworthy source of information, especially what comes to the strategically sensitive economic issues.

In secondary data collection, the authors have come upon considerable disparities between the Russian data and these originating from other countries. In compiling our dataset on Russian enterprise sector, we aim at continuous dialogue between different approaches to often contradictory issues, such as enterprise management, company performance and governance etc. Thus, our purpose is to provide an unbiased insight into a contradictory phenomenon, likely resulting in different conclusions than what would have been achieved by, for instance, a pre-designed survey among Russian managers and policymakers. 
During the research process, we have undertaken numerous supporting discussions with leading business and governmental experts on Russia (both from Russia and other countries) to validate our views based on the secondary data. These complementary discussions have provided us with a multifaceted approach to the subject and enable more solid and independent conclusions.

\section{Privatisation and corporate governance in Russia}

\section{Privatisation and corporate governance development on the macroeconomic level}

In comparison to the other transition economies in Central and Eastern Europe, CIS countries in general have been more cautious in implementing transitional reforms in the area of enterprise restructuring. The European Bank for Reconstruction and Development (EBRD) assessment in 1996 categorises most of the Central-Eastern Europe and the Baltic States as "countries in advanced state of transition" and the CIS countries in the intermediate or low transition stage categories. The following review concentrates on the developments in the CIS.

The private sector share of the GDP in 1996 (the starting point for our review period) ranged from 15 to 50 per cent in all CIS countries except Russia, where the private sector share had reached 60 per cent in the wake of voucher-based mass privatisation schemes in 1993-1994. More than 15.000 medium to large companies employing more than 80 per cent of the work force experienced ownership transfer to private entities. The cash-based second phase of privatisation was initiated in the beginning of 1995; a continuation of fast and revenue-maximisation oriented policy, but which, in the end, led to significant controversies. After 1996, the pace of privatisation in Russia has been slow, as a new approach aimed towards transparency and enterprise restructuring was taken by the government (EBRD 1996). Figure 1 plots CIS countries on the dimension defined by the 2005 level of privatisation (a rough estimate of the EBRD) and the pace of change during the last 10 years.

Ukraine and Kazakhstan, among others, have been active in their privatisation schemes during 1996-2005. They have reached a similar level in the share of private sector of GDP as Russia, who achieved their most significant development during the first half of the decade. Many of the privatisation plans were held off and have not yet become part of Russian reality, a fact of which good examples are some of the major corporations in Russian industries. Belarus has a story of its own with changing registration policies during late 1995 largely halting the privatisation and corporatisation processes; consequently their position in the lower-left, poor-results/no-effort -quadrangle. 
Figure 1. Development of privatisation during 1996-2005 in the CIS

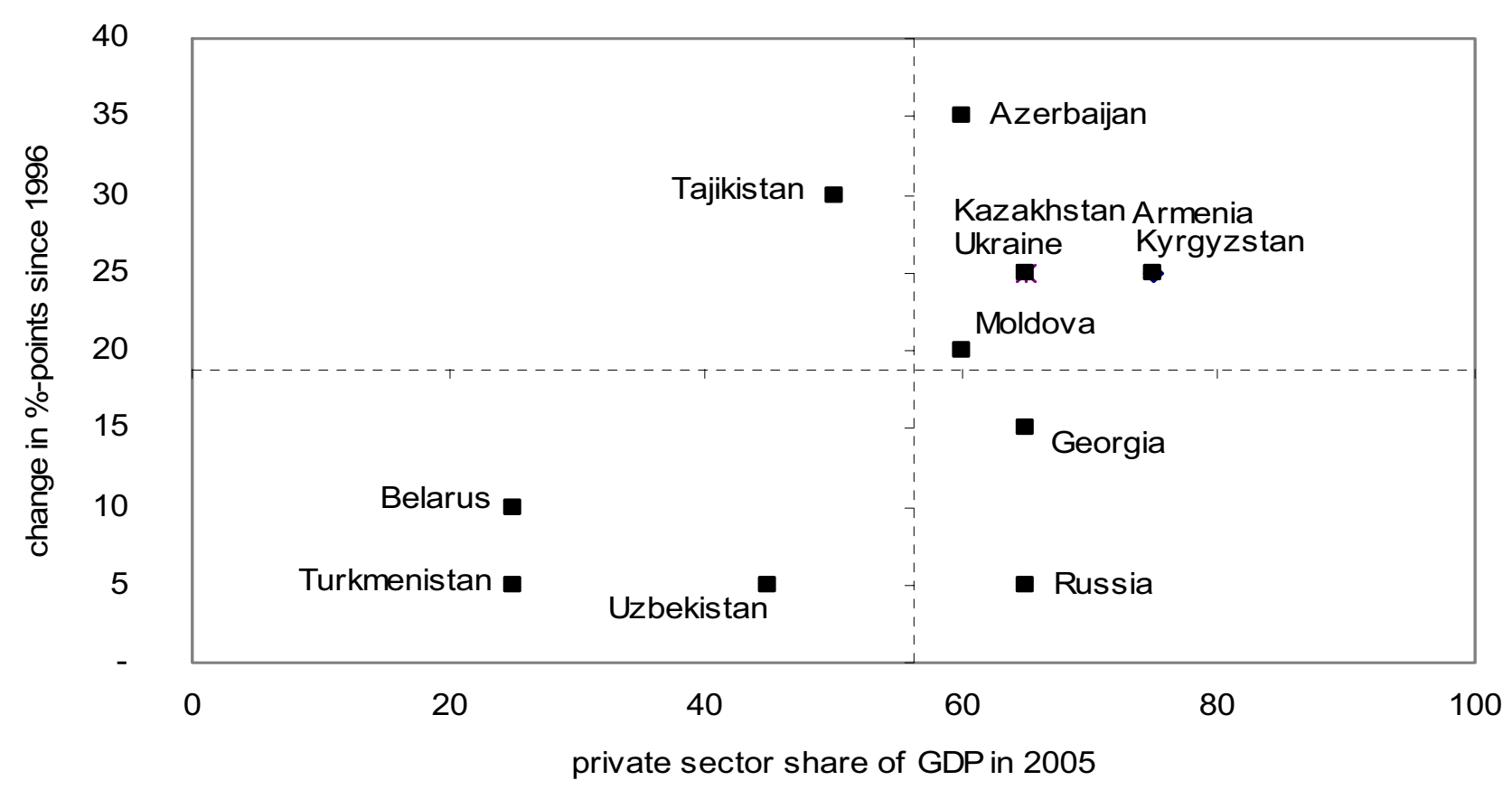

Sources: EBRD 1996, 1997, 2004, 2005.

During the focus period the level of private sector share of GDP in the CIS countries has actually decreased only twice. The first of these rare occasions took place during 1998-1999 in Moldova, where the political situation has been somewhat unclear with signs of re-nationalisation souring the investment climate. The second is more recent and indeed interesting from this article's point of view: the indicator dropped from 70 to 65 per cent in Russia during 2004-2005. The reasons behind the negative development in Russia are predominantly the re-nationalisation of large companies in the oil and gas sector. In addition, the decisions to increase regulation in the "strategic industries", has increased the state's involvement in the enterprise sector (EBRD 2005). The future will tell whether this divergent development from most of the other major CIS countries continues to broaden. Currently the level of privatisation ranges from 25 per cent (Belarus, Turkmenistan) to 75 per cent (Armenia, Kyrgyzstan) among the CIS countries.

Enterprise restructuring and the development of corporate governance in the CIS, are also of significance in the scope of this article. Until 1996, the predominant source of restructuring had been the tightening of access to government subsidies and soft bank credits, as well as the increased scope for import competition and the liberalisation of new enterprise development. However, the implementation of stronger bankruptcy laws had so far been on the backburner. In Russia, the level of government subsidies to firms and individuals experienced a significant drop, from 23 per cent of GDP in 1992 to 
approximately 2 per cent in 1995, demonstrating a significant improvement in the restructuring of the enterprise sector (EBRD 1996).

In the area of corporate governance the newly formed financial-industrial groups pushed for improved management practices and corporate governance in their respective conglomerated companies (EBRD 1996). This favourable development during 1996-2005 in Russia, as well as in other CIS countries measured by the five category index for governance and restructuring ${ }^{1}$, is depicted in the Figure 2.

The current state and the ten-year change-oriented set-up in Figure 2, allows us to distinguish between above and below average countries in terms of current position, and the positive or negative development during the ten-year focus period. Russia managed to improve its position with the change of the millennium, by initiating reforms on bankruptcy laws in 2002, and due to the continued momentum from financial-industrial groups to modernise corporate governance practises in large companies. However, due to the lack of stimulants from the areas of ownership right reforms and increased competition, the restructuring process is just beginning to take hold in many companies which are smaller in size.

Belarus is the underperformer of the group, while Ukraine and Kazakhstan perform above average even though they have not achieved any significant change since 1996. It is important to note, that in the five-step category of the index $(1-4+)$, all the CIS countries lie in the range of 1 to 2.3 , with only one country crossing categories into a positive direction, namely Tajikistan. The changes have been marginal in their proportions, if any. In real terms, there has been no significant improvement during the last ten years from the regime of moderate policies and weak enforcement in the area of corporate governance and restructuring in the CIS. A significant and sustained action in the promotion

1 The EBRD index for corporate governance and restructuring involves a five step categorisation:

Category 1: Soft budget constraints (lax credit and subsidy policies weakening financial discipline at the enterprise level); few other reforms to promote corporate governance

Category 2: Moderately tight credit and subsidy policy but the weak enforcement of bankruptcy legislation and little action taken to strengthen competition and corporate governance

Category 3: Significant and sustained actions to harden budget constraints and to promote corporate governance effectively (e.g. through privatisation combined with tight credit and subsidy policies and/or the enforcement of bankruptcy legislation)

Category 4: Substantial improvement in corporate governance, for example, an account of an active corporate control market; significant new investment at the enterprise level

Category 4+: Standards and performance typical of advanced industrial economies: effective corporate control exercised through domestic financial institutions and markets, fostering market-driven restructuring 
of corporate governance and standards of conduct seem to be lacking across the spectrum.

Figure 2. Corporate governance and restructuring during 1996-2005 in the CIS

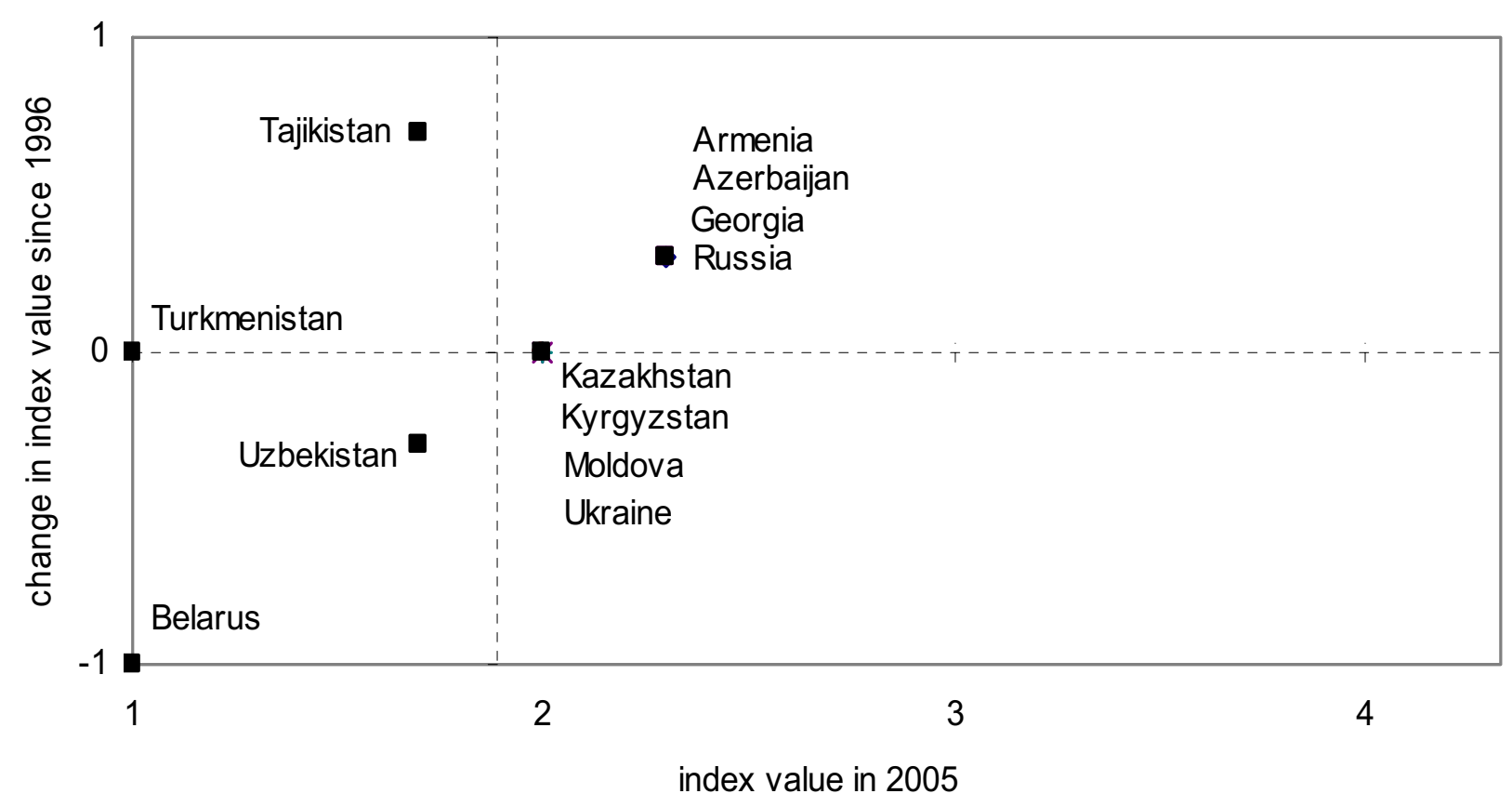

Sources: EBRD 1997, 1998, 2004, 2005.

The current state and the ten-year change-oriented set-up in Figure 2, allows us to distinguish between above and below average countries in terms of current position, and the positive or negative development during the ten-year focus period. Russia managed to improve its position with the change of the millennium, by initiating reforms on bankruptcy laws in 2002, and due to the continued momentum from financial-industrial groups to modernise corporate governance practises in large companies. However, due to the lack of stimulants from the areas of ownership right reforms and increased competition, the restructuring process is just beginning to take hold in many companies which are smaller in size.

Belarus is the underperformer of the group, while Ukraine and Kazakhstan perform above average even though they have not achieved any significant change since 1996. It is important to note, that in the five-step category of the index $(1-4+)$, all the CIS countries lie in the range of 1 to 2.3 , with only one country crossing categories into a positive direction, namely Tajikistan. The changes have been marginal in their proportions, if any. In real terms, there has been no significant improvement during the last ten years from the regime of moderate policies and weak enforcement in the area of corporate governance and restructuring in the CIS. A significant and sustained action in the promotion 
of corporate governance and standards of conduct seem to be lacking across the spectrum.

The above considerations on privatisation and corporate governance are important factors in determining investor confidence and consequently the direction of economic development in Russia. Perotti and van Oijen (2001) argue that the resolution of political risk resulting from successful privatisation has become a significant factor in supporting the rapid growth in stock valuation in the emerging market economies (EME). The determinants of FDI in transition economies have been argued to correlate with, for example, country risk, which in turn is influenced by private sector development in general (Bevan/Estrin 2000). In addition, Jensen (2002) has confirmed the significance of political factors, such as the level of economic reform and level of state capture by the political and economic elites, to the volume of transition economy FDI inflows.

Along with these findings that establish the relationship of investor confidence and economic development in the form of both portfolio and direct investment contribution, we may take into consideration the observations on FDI inflows to Russia and integrate them to the previously presented elaborations on privatisation and corporate governance. Figure 3 depicts the development of annual FDI inflows during the last decade and plots the significance of the same to the Russian economy, namely the nominal GDP.

The bump in the 1998 FDI inflow share of nominal GDP is mainly due to the financial distress of the time, as the value of the rouble depreciated against the USD. With a relatively more stable exchange rate development after 2000, the figures are more informative. The accumulated FDI inflow during 1-3Q '05 made 2.60 per cent of the Russian nominal GDP: a significant rise from the trough of 2001 with its 0.93 per cent contribution. We can make cautious inferences that the favourable development in corporate governance as well as the stable and high share of the private sector in the economy has increased investor confidence, a fact that is confirmed by A.T. Kearney's investor confidence ranking of Russia as the $11^{\text {th }}$ most attractive market in the world (A.T. Kearney, 2004). However, while the ranking has already declined from previous years, due to unfavourable developments in the level of political risk, the FDI figures show no downward movement. This suggests a twofold impact of increasing state control in the Russian industry on the country's investment profile - despite the increased political risk in Russia due to state interventions in the enterprise sector, these recent developments have not undermined foreign investor confidence. This paradox will be discussed in more detail in the following section. 
Figure 3. FDI inflows and its importance in Russia during 1997-2005

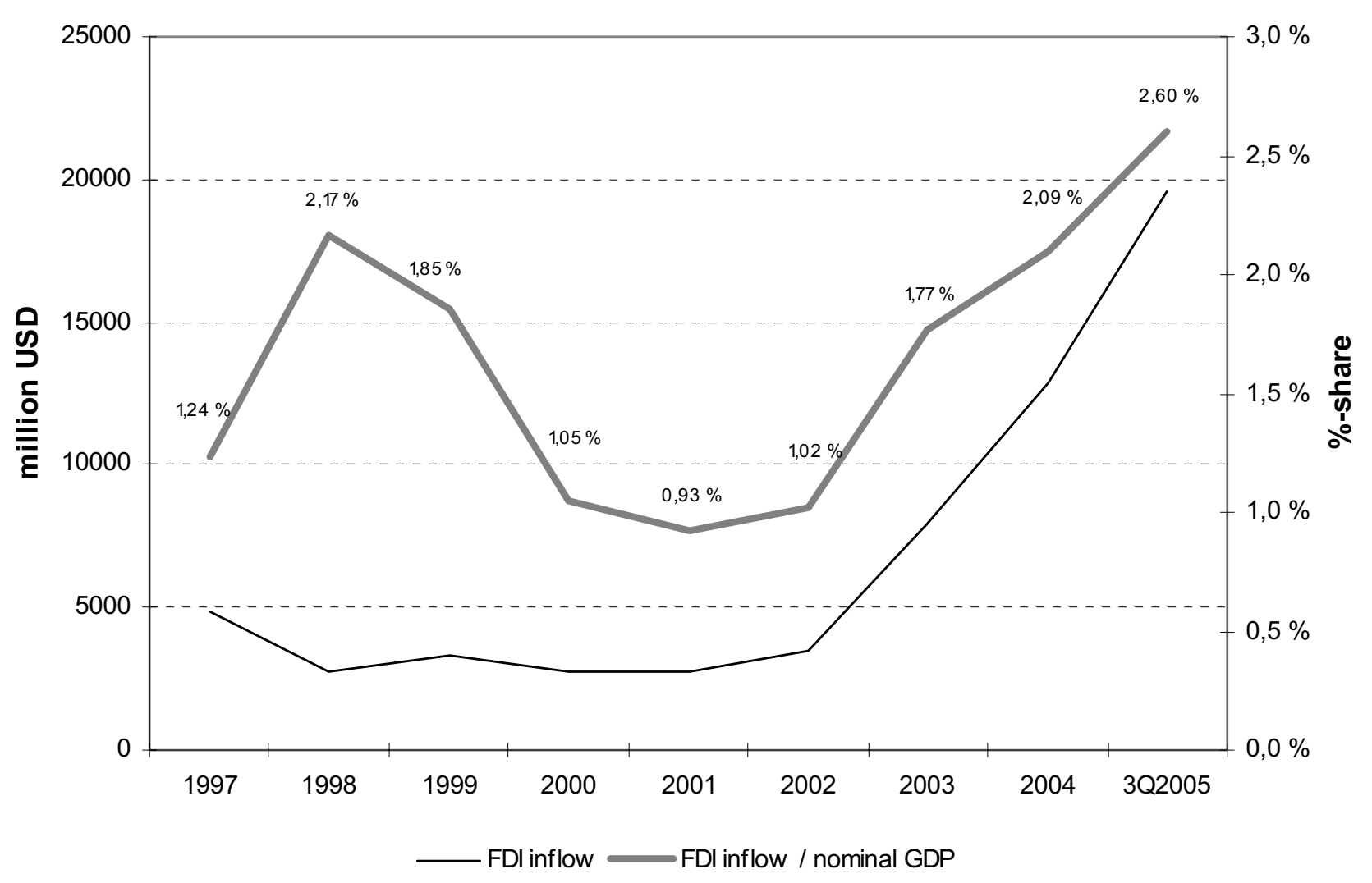

Source: Russian Central Bank 2006.

\section{Privatisation and increasing state control on the enterprise level}

As indicated by the decreasing share of the private sector in the Russian GDP, the past years have been marked with a considerable increase in state control over the country's major industrial assets. Through a series of ownership arrangements initiated by the notorious probe around the country's once-largest oil producer, Yukos, the Russian State is effectively regaining control over several companies in strategic industries. While widespread concerns have been voiced, on ownership rights, institutional development, and the functioning of the legal system in Russia, the increased state control has not entirely been met with antipathy - the turnover and value of Russian stock exchanges have hit record-high levels, and international investors are hailing the upcoming IPO's of newborn or restructured Russian state-owned companies on the major stock exchanges of the world.

Hence, when discussing the increasing state leverage and control over Russian industrial assets, we are bound to consider the matters of increased investor confidence and, in some instances, greater transparency delivered by state ownership of these Russian enterprises. In the following, we provide three divergent company cases, which highlight the recent developments in the balance between public and private ownership in Russia. These brief company 
cases are followed by discussion about the corporate governance implications of the recent changes in industrial ownership and control in Russia.

\section{Gazprom: liberalisation and state control}

Gazprom's share market liberalisation and the removal of the ring-fence ${ }^{2}$ initiated in 2005 were among the most significant recent developments in the Russian enterprise sector. After the collapse of the Gazprom and Rosneft merger in 2005, the Russian government introduced an alternative plan and arranged a purchase of an additional 11 per cent of Gazprom's shares, accumulating a majority stake in the company. As of the end of 2005, the government directly owned 50 per cent +1 share in Gazprom, while controlling additional 4.55 per cent through subsidiaries.

Along with the accumulation of a controlling stake, a liberalisation plan for Gazprom's shares was introduced. Most importantly, the steps of implementation of the plan included the lifting of limitations on the trading of Gazprom's shares by foreign investors on Russian exchanges and lifting the $20 \%$-limit on foreign ownership of the company's shares. The share liberalisation proved very successful in terms of attracting investors; the shares of the company surged over $60 \%$ during the first half of 2006. As of September 2006, Gazprom ranks as the world's third-largest company by market value, behind Exxon Mobil and General Electric.

The dramatic shift in plans in just 12 months, from integrating Gazprom and Rosneft to the restructuring and liberalisation of Gazprom shares implied strong backing at the highest federal level. Whilst the removal of the ring-fence can be expected to deliver positive effects, particularly in the field of corporate governance, the growing urge of the government to actively control the country's major energy assets should not be overlooked. As witnessed by another major event in Russia's energy sector in 2005, the liberalisation of Gazprom shares came with the price of further consolidation of the sector.

In late 2005, Gazprom purchased 75.7 per cent of the shares in Russia's fifthlargest oil producer, Sibneft, from its principal owner, Millhouse Capital, associated with Russian industrial magnate, Roman Abramovich. The \$13billion deal, combined with the earlier takeover of Yukos' main production subsidiary, Yuganskneftegaz, by state-owned Rosneft, consequently put the state in control of roughly a half of Russia's oil production, compared to just below 4 per cent in 2003.

2 Isolation from external ownership 
Svyazinvest: a long way towards privatisation

Svyazinvest is Russia's state-owned telecommunication holding and fixed-line monopoly, comprising several regional fixed-line operators. The government currently owns a 75\%-share in Svyazinvest, valued at $\$ 5$ billion, with the remaining 25 per cent belonging to another Russian financial-industrial holding, Access Industries ${ }^{3}$. As an owner of the blocking share in Svyazinvest, Access Industries holds the right to intervene in any future reorganisation of the holding.

The privatisation of Svyazinvest has faced numerous delays during the recent years, due to the somewhat mixed interests of the groupings inside the Russian Government. Included in the group supporting privatisation are the liberalminded top officials from the Telecommunications Ministry and Svyazinvest. The voices hindering privatisation include the military and government security agencies, afraid of losing their preferential tariffs, and facing more operational restrictions with the Russian fixed-line network in private hands. However, the two strategic groupings have already been promised preferred treatment and considerable subsidies to set up networks of their own once the Svyazinvest privatisation is completed.

The delay in privatisation implies notable strategic governmental interests around the holding. The latest developments suggest two possible paths for further development. The first scenario is likely to involve an auction during 2007, as the government is narrowing the list of suitable buyers for its $75 \%$ stake. Another scenario involves a halt in the privatisation process and the government retaining its majority stake in the company, in line with its recently increased interest towards companies in strategic industries (see also Section 5).

Whichever the ultimate outcome of the Svyazinvest case, it is obvious that the Russian government is not eager to hand over the control of a company that controls more than 70 per cent of the country's telecommunications infrastructure, to a foreign owner or even a private Russian holding. Hence, even if followed through, the privatisation process is destined to leave the government with certain leverage over Svyazinvest through a manageable domestic buyer.

\section{AvtoVAZ: strengthening control}

Russia's largest carmaker, AvtoVAZ, has been one of the flagships of the Russian machinery sector, ever since the Soviet era. For domestic car manufacturers, recent developments in the Russian passenger car market have been troubling at best. Their weak quality of production, troubling financial conditions and a growing demand for foreign cars have driven many domestic

3 The principal shareholder of Access Industries, Leonard Blavatnik, bought the share from the Mustcom consortium belonging to George Soros. 
producers to the verge of bankruptcy. Moreover, the expected WTO membership of Russia has been predicted to hit domestic automotive and other manufacturing industries hard.

In the turn of 2005-2006, the Russian government ministries prepared a proposal, signed by President Putin, for the formulation of a state-owned corporation comprising car, truck, and bus production. With AvtoVAZ as its flagship, the corporation is intended to counterweight the increasing foreign competition on Russian markets. Likely, the state-run automotive holding is to include, besides AvtoVAZ, the major truck manufacturer, KamAZ, and off-road vehicle and truck manufacturer GAZ.

The state-owned armament trader, RosOboronExport, emerged as a vehicle for the consolidation process with more than 100 executives of the holding taking control over AvtoVAZ in late 2005. Preceding the sudden change in the company's management, the former owners of AvtoVAZ, led by Vladimir Kadannikov, swiftly sold out their shares in the company to undisclosed buyers. Although the current ownership structure of the company remains obscure, the state is likely to appear as a direct majority holder in AvtoVAZ in the near future.

As the case of AvtoVAZ indicates, the government is looking to increase its control over the key sectors of Russian industry even beyond the natural resource-based sectors. In many aspects, however, increasing the state's control over the troubled carmaker may be regarded as a positive development for the company. For AvtoVAZ, the acquisition essentially means even stronger state support and likely improvements in its financial conditions; as a governmentbacked company, the credit profile of AvtoVAZ should witness some improvements among investors at least in a short run.

\section{Implications of increased state control for corporate governance}

As indicated by the above cases, several divergent sectors of the Russian economy are currently undergoing significant changes in regards to ownership and control. The current restructuring of the Russian industrial sector is essentially about striking a balance between public and private ownership, with both the economic and political lines of consideration present. Below, we provide some insights into the economic impact of the current redistribution of ownership in the Russian industry, with a focus on the corporate governance performance of the companies involved.

As elaborated upon earlier, the impact of increased state ownership and control is essentially twofold. The deteriorating effects of such a development occur at both national and company levels. While the former category includes the reduced credibility of the Russian institutional and legal environment as well as deteriorating ownership rights, the negative effects on the company level are more diverse. As the federal and regional governments regain stakes in private 
companies, the processes have more often than not included a violation of the rights of minority shareholders. In addition, often being in positions of operating companies for their personal benefit, the managers of state-owned companies have a record of corporate governance violations. In addition, as indicated by several earlier studies, state-owned companies have repeatedly been found to be inferior to private enterprises in terms of efficiency and performance. As indicated in the report by Troika Dialog (2006e), the level of corporate governance in Russia deteriorated in 2005, along with a drop in the number of well-governed companies. While the reasons can be found in many contradictory ownership arrangements throughout Russian industry, the increase of state ownership and related violations of minority shareholder rights play a notable role in this development.

However, to obtain a comprehensive overview on recent developments, one should not only focus on the detrimental effects of increased state ownership in the Russian industry. When many of the formerly private companies controlled by oligarchic groupings have poor transparency and disclosure records ${ }^{4}$, state ownership means a considerable enhancement of the level of transparency of the companies involved. In addition, the financial support through restored state ownership may be viewed as a last resort for financially troubled and mismanaged enterprises of national strategic interest, such as the case company AvtoVAZ.

Furthermore, whilst international observers grow increasingly concerned over institutional and legal developments in Russia, the investment community has often welcomed the increased state leverage in Russian companies as a provider of additional stability on the Russian market. In an environment characterised by relatively high political risk, increased state ownership interests in the companies is often perceived by investors as offering an additional safeguard against future political interventions. As a result, the planned IPO's of several majority state-owned companies have raised enormous interest among international investors. Here, however, one needs to make a distinction between the positive reactions among the portfolio investors and the often negative attitudes of strategic investors, who are likely to be more concerned about the increased state ownership and its detrimental effects on enterprise development.

4 For instance Sibneft and AvtoVAZ have a long record of poor organisational transparency. Neither of the companies officially revealed the real structure of ownership behind the nominal shareholders. 


\section{A discussion on strategic government policies $^{5}$ in Russia}

In the previous sections, we have dealt with privatisation and corporate governance on the macroeconomic level and provided company examples of increasing state control in Russia. This section further elaborates on the increasing state leverage in the Russian economy by discussing the development of strategic government policies in Russia.

Strategic government policies strengthened in early 2005, when Russia's President Vladimir Putin requested the government to prepare legislation to block or restrict investment by foreigners in certain strategic assets having a nexus with the country's national security, such as military sites, large mineral deposits and other key natural resources and natural monopolies (Satrom/Zhdanov, 2006).

In October 2005, Yury Trutnev, Natural Resources Minister, stated that Russia should limit foreign participation in three main areas. First, the ministry wanted limits on foreign participation in auctions for natural resources that are scarce, such as diamonds, uranium, and quartz. Second, foreign firms were to be banned from large mineral deposits with more than 150 million tonnes of oil and one trillion cubic meters of gas, but large remote offshore fields could still be developed by foreign ventures. Trutnev named three such fields; the Titov and Trebs oil field in Timan Pechora and the Chayadinskoye gas field in East Siberia. He also added that Euroasia's largest gold deposit Sukhoi Log and the Udokan copper field would also be classified as strategic. Third, foreign participation was to be restricted in fields close to military sites (Alexander/Oil, 2005; Aton Capital, 2006b; BEE, 2006).

In addition to these restriction plans related to strategic natural resources, the Russian government aimed at restricting the participation of foreigners in areas related to security. In the beginning of March 2006, German Gref, Minister of Economic Development and Trade, informed about a bill aiming towards restricting foreign access to 39 types of activity linked with the production of weapons and military hardware, nuclear materials and nuclear facilities, the space industry and aviation (Interfax, 2006).

After a heated debate about strategic sectors in the spring of 2006, the discussion received even more negative tones a few months later, when Minister Trutnev

In this article, the strategic government policies refer to the underlying ideology, policies and practices of Russia's presidential administration and the Russian government. These government policies are termed as strategic since the discussion on the state's strengthening involvement in the Russian economy is frequently labeled under the term "strategic". In reality, strategic government policies mean the state's goal to increase its direct and indirect control over key sectors of the Russian economy. These key sectors have not been defined explicitly but obviously they refer to the sectors, which are essential for the national security and the economic development of the Russian Federation. 
suggested a lowering of the bar for strategic oil and gas fields (Troika Dialog, $2006 \mathrm{a} / \mathrm{b}$ ). After the discussion in June, the debate on strategic government policies has become less public. Despite this disappearance of public debate on strategic government policies, one may anticipate that debate continues behind the scenes.

As one cannot find the answer from official statements addressing the question, what is the future development of the strategic government policies in Russia, one should search for the answer from the underlying rationality behind strategic government policies by analysing sectors strategic for national security and sectors strategic for economic security. With these two dimensions the authors have created the following figure.

The militarily sensitive sector is strategic for Russia's national security, similarly as the economically sensitive sector is strategic for the country's economic security. The top sensitive sector stands for those industries which are highly strategic for both national and economic security. Vice versa, the nonsensitive sector has lower strategic importance in both these dimensions.

The main idea behind classifying Russia's key industries using these two dimensions is to anticipate the role of foreign firms in the aforementioned sectors. The top sensitive sector is most likely to experience the most serious direct and indirect restrictions. The non-sensitive sector is likely to remain open, also for foreign businesses. The remaining two sectors will probably experience certain limitations but the criteria behind these restrictions will be different.

Most probably, the likelihood of restricting or even blocking foreign participation will be highest in the top sensitive sector, i.e. one may anticipate new controlling measures in the future. The non-sensitive sector probably stays open for foreign companies also in the foreseeable future. Should the role of the siloviki in the key positions of the economy strengthen, it seems probable that the state takes a stronger grip on both the militarily sensitive sector and the economically sensitive one. In other words, it is probable that some of the industries or the most important corporations in these industries will go up in the national security dimension. It is not a completely excludable option that the decision criteria to raise their militarily strategic status would depend only on their significance to national security but rather on the Kremlin's pattern of strengthening their loyal oligarchy, i.e. to broaden the network of loyal persons in the strategic sectors and provide them with financial courtesy via ownership in key corporations.

A few clarifying comments are needed to better understand why some industries have been positioned in the table in a certain place. To begin with the nonsensitive sector, one may easily comprehend why the production of consumer goods is neither strategic to the country's military safety nor economic security, as their production is not so essential for either national security or economic 
development. The same applies to retail trade and construction, though some Russian oligarchs have comprehended their growing economic value, as private consumption has grown around $10 \%$ a year throughout this decade and the growth in construction will probably last for decades (EIU, 2006).

Figure 4. Classifying strategic government policies in Russia

Strategic for national security

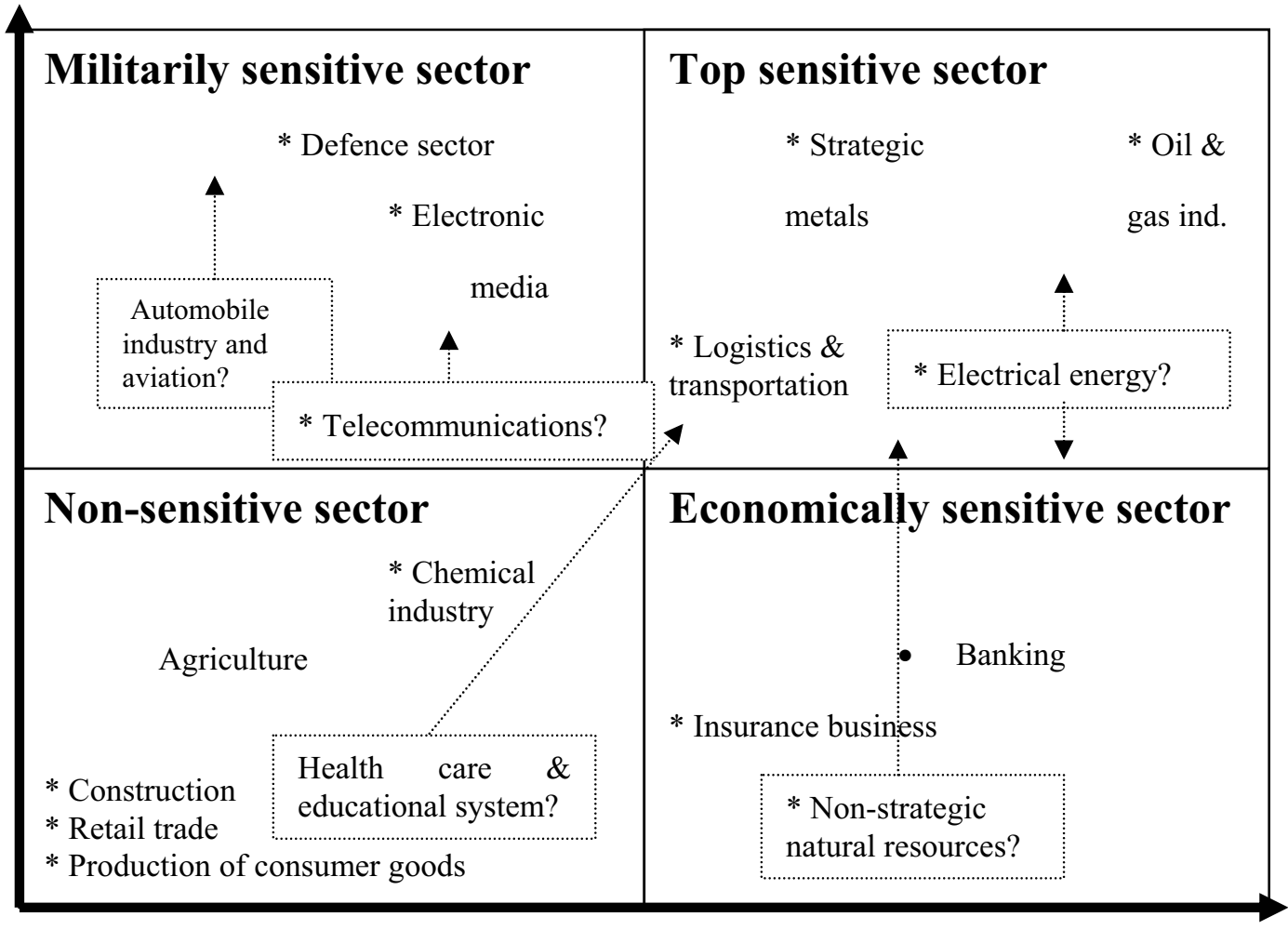

Strategic for economic security

The health care and educational system of Russia has traditionally been peripherally located in strategic government policies. However, its position may change considerably, if the serious fast-spreading diseases, such as bird flu and HIV/AIDS, threaten the Russian population. Even without any pandemic disease, the rapidly declining population, along with the deteriorating and significantly underfinanced education system threatens the country's future competitiveness. It is probable that the health care and educational system will attract more attention from the Russian leadership in the future (e.g. the national priority projects on healthcare and education), which may lead to tightening regulations in this sector, and hence, it may become more restrictive towards foreigners (Moscow News, 2006).

Even if agriculture's share in the Russian GDP is not particularly high (5.6 \%), one should bear in mind that agriculture employs a tenth of the Russian workforce and close to one fifth of Russian imports consists of food and agricultural products. For a country with a population of almost 145 million, this 
is a security concern, especially if the global situation of the foodstuffs safety worsens. Already, increasing strategic attention towards agriculture may have been observed (e.g. the national priority project on agriculture). Furthermore, it is interesting to notice that some Russian investors, probably guided by the Kremlin, have started to invest in agriculture, although the return on investment is much higher in several other sectors (EIU, 2006; Korchagina, 2006).

The state's increasing interest in the automobile industry has raised some suspicion. At the end of 2005, the state took over the largest automobile producer, AvtoVAZ, and soon thereafter, the consolidation plans of the main actors in the Russian automobile industry have received support from the Kremlin (Moscow Times, 2005; Aton Capital, 2006a). A similar consolidation process has also begun in the aviation industry, which has heated up discussion on re-nationalisation (BOFIT, 2006a). Some argue that the state aims at regaining control over these sectors in order to improve their competitiveness, i.e. the state tries to secure the jobs that these industries provide. Others believe that strengthening military thinking in the economy is the hidden motive behind re-nationalisation. Should the latter scenario be the case, the military sensitivity of these industries increases considerably.

The chemical industry plays a rather important intermediary position in the Russian economy. The chemical industry provides materials to several key industries, such as the oil and gas sector and even to the military (Vahtra/Liuhto, 2004). This interdependency relating to the chemical industry makes it sensitive, even if it still today can be classified as a non-sensitive sector. However, if the military drift in Russia continues, it cannot be completely ruled out that the chemical industry would move towards the security sensitive sector.

Telecommunications is an important tool for the army, the police and the security services, and therefore, some peculiar regulations have been adopted in this branch. Although mobile telecommunications has been rapidly developed by private companies, the fixed lines are still controlled by the state. The privatisation of the fixed lines has been hampered for several years, which may signify the reluctance of the state to liberalise it (Troika Dialog, 2006d). Furthermore, the aggressive strategies of the mobile sector's key player, Altimo, owned by Alfa Bank, have intensified the discussion about the future position of foreign firms in the Russian telecommunications sector (Troika Dialog, 2006c). Even if Minister Gref's statement (RIA Novosti, 2006b) - "The Russian Government has forgotten all about telecommunications, thank God, so it's one of our most briskly developing sectors. If the government undertakes to regulate the telecommunications and mobile communications sector, we will have no mobile phones [left]." - is encouraging, one may only hope that this particular statement will remain valid after the election of the new president and the formation of a new government in 2008 . 
Russia's free media has stagnated in this decade. Even if control over Russia's printed media is not as strong as one could assume from the Western news, the country's electronic media has been taken over by companies close to the Kremlin. It is important to remember that the electronic media is not as much strategic with regard to national security as it is for political dominance. Therefore, the electronic media can be classified as belonging to either the security sensitive sector or even to the top sensitive sector (EJC, 2006).

The position of the army and the defence sector as a whole has clearly strengthened in Russia during Putin's two presidencies. The budget spending, particularly the invisible one, on the army and military technology has increased. The increased budget spending is, on one hand, due to the fight against terrorism as well as military modernisation, and on the other hand due to the country's overall aim at strengthening its military capability internally and externally (Moscow News, 2006; RIA Novosti, 2006a).

According to Vladimir Taraskin, Director at the Ministry for Industry and Energy, there is a proposal to include the electricity sector, particularly wholesale generating companies, in the law on strategic industries (Interfax, 2006). As the electricity energy sector is a high voltage issue, its security sensitivity may soar in the future despite its ongoing privatisation process. Therefore, it is essential to follow into whose hands these privatised energy assets will fall. Here, it is necessary to remind oneself that privatisation in Russia does not necessarily mean that the state would not retain indirect control over them.

Logistics and transportation is a multisided sector in terms of its security dimension. On the one hand, the state tries to attract foreign firms to upgrade the soft sides of it, i.e. non-infrastructural components. On the other hand, the state's interest in controlling infrastructure, such as pipelines, ports and railroads, has grown further (e.g. Transport Strategy, 2005).

Strategic government policies are clearly observable in strategic metals. One can observe strengthening state interest in Norilsk Nickel, the leading metal producer of Russia (Aton Capital, 2006a). Similarly, Russia's main titanium producer, VSMPO-Avisma, has dropped into the hands of Rosoboronexport, the state arms trader of Russia (Aton Capital, 2006d; Moscow Times, 2006a). Correspondingly, the aluminium industry is concentrated in the hands of a Kremlin loyalist (Aton Capital, 2006e; BOFIT, 2006b; Moscow Times, 2006b).

The most sensitive sector out of all the Russian businesses is the oil and gas industry, as it is the principal source of the country's budget income and export earnings. At the beginning of the decade, private companies accounted for the bulk of Russian oil production, while natural gas remained practically in the hands of state-controlled Gazprom (Liuhto, 2002). After the acquisition of Yuganskneftegaz by Rosneft and the acquisition of Sibneft by Gazprom, state- 
led companies currently represent clearly over half of all Russian oil production. It is not a completely excludable scenario that the state reintegrates all the stateowned oil units under one holding after the bankruptcy of Yukos. Correspondingly, in the natural gas sector, one should not think that a certain ownership liberalisation by Gazprom would mean that the state would be abandoning its control over it. Obviously, the state allows foreigners to benefit economically from the development of the oil and gas industry but is extremely reluctant to give control to foreigners, i.e. foreign capital and know-how is accepted but control is not given in return.

Non-strategic natural resources, such as non-strategic metals, forests and land per se, are currently only economically sensitive in Russia. However, as enormous economic values surround these sectors, it is possible that the Kremlin directly and indirectly supports Russian firms over foreign ones in the future. Also the Kremlin loyalists may recognise that non-strategic natural resources also offer an easy means to increase personal prosperity, and therefore, they may be tempted to use various artificial reasons, based either on national security or pride of national ownership to gain their stakes in these fields. Interesting enough, a strong consolidation movement currently occurs in the Russian steel industry. Probably, the Russian steel industry will concentrate around the Kremlin-loyal oligarchs (Aton Capital 2006c/f).

The insurance business is still rather undeveloped in Russia, and hence, foreign access has been restricted. The Russian insurance industry is subject to a $25 \%$ limit on participation by foreign entities in the aggregate capital of the Russian insurance companies. A Russian insurance company whose charter capital is more than $49 \%$ held by foreigners becomes subject to certain qualitative limitations upon the scope of its activities, i.e. it cannot offer life insurances. Various regulations will also keep foreign firms outside the most sensitive parts of the insurance business in the future, unless Russia's WTO accession requires the restrictions to be abolished. Should this happen, it is probable that a certain transition period will be put into place (Satrom/Zhdanov, 2006).

A functioning banking sector is strategic to any economy. As Russia's banking sector is still relatively weak, it is understandable, why the state considers it economically sensitive, and hence, the entry of foreign banks is somewhat restricted. A historical quota restricted foreign capital participation in the Russian banking sector to $12 \%$ of the aggregate amount of charter capital of all Russian banks. Even if this quota has later on been cancelled, some Russian bankers have recently asked the government to reinstate it, as foreign ownership has reached $11 \%$ at the end of 2005 .

Some members of the Duma have declared that there is no need to impose an ownership quota as long as the ban on foreign banks' branches remains in place. In a similar tone, President Putin has stated that the ban is an element of Russia's ongoing fight against terrorism and money laundering, which has 
obviously created difficulties in WTO negotiations with the USA. Even if Russian legislation bans foreign branches, foreign banks have the possibility of establishing their unit in Russia or to buy a stake in a Russian bank. In the beginning of 2006, approximately 40 wholly-owned foreign banks and another 91 banks with foreign ownership operated in Russia. The Russian banking sector nowadays includes some 1000 banks altogether. Their number, however, is believed to dramatically diminish in this decade (Satrom/Zhdanov, 2006).

To conclude, this section has speculated about the strategic government policies in Russia. Currently, it seems that strategic government policies gain weight in Russia. If this is to continue, it would probably lead to lower GDP growth rates and a weakening of the position of foreign firms in industries outside the nonsensitive sector. It is important to remember that Russia is not doomed to the security-dominated scenario, but in order to avoid such a pitfall, it has to strengthen its liberal policies. Here, one needs to stress that it is unlikely that liberal policies can be strengthened if liberally-minded decision-makers and advisors became a rarity in the presidential administration and the government.

\section{Conclusions}

During 2004-2005, the private sector share of GDP in Russia decreased for the first time since the beginning of the transition period, indicating increased state involvement in the enterprise sector. While earlier studies generally confirm the superior performance of private companies over state-owned ones, the increased state ownership in Russian industry has thus far had little if any negative impact on investor confidence and FDI flows in Russia.

As indicated by investor reactions, the impact of increased state control in Russian industry is essentially twofold. The detrimental effects of regained state-ownership may include the reduced credibility of the Russian institutional and legal environment, deteriorating ownership rights and mismanagement of companies and other corporate governance violations. On the other hand, increased state ownership has, in some instances, resulted in increased organisational transparency and assisted in improving the financial conditions of troubled companies. Furthermore, portfolio investors in particular have regarded increased state-ownership in strategically sensitive industries as a safeguard against unexpected political interventions.

Notwithstanding the positive reactions among the international investment community to increased state-ownership in some instances, the long-term effects of increased state leverage are likely to include deteriorating enterprise performance, lower GDP growth rates, and the weakening position of foreign firms in many industries. The recent strategic government policies in the Russian economy suggest increasing limitations to foreign participation in several Russian industrial sectors. In contrast, along with the upcoming WTO 
membership, the Russian economy should become more open towards increased foreign participation through imports and, consequently, FDI. The question remains, how the balance between economic and strategic interests in the Russian enterprise sector will be maintained. In reaching this balance, the liberalisation of governmental policies towards several sectors of the economy plays the key role.

\section{References}

Alexander Gas/Oil (ed.) (2005): Trutnev names Russia's strategic deposits, Alexander's Gas \& Oil Connections: News \& Trends: CIS/Russia Vol. 10/Issue 21, http://www.gasandoil.com.

A.T. Kearney (ed.) (2004): FDI Confidence Index, Global Policy Council, Vol. 7, http://www.atkearney.com.

Aton Capital (ed.) (2006a): Avtoprom consolidation: in the fast line, February 1, http://www.aton.ru.

Aton Capital (ed.) (2006b): Ministries sign off on new bill requiring Kremlin approval for foreign investment in strategic sectors, March 2, http://www.aton.ru.

Aton Capital (ed.) (2006c): Evraz Group - Millhouse affiliate acquires 41\% stake, June 20, http://www.aton.ru.

Aton Capital (ed.) (2006d): Rosoboronexport stake acquisition reportedly underway, June 28, http://www.aton.ru.

Aton Capital (ed.) (2006e): Metals sector - Rusal to buy Sual, creating leading global aluminium company, August 30, http://www.aton.ru.

Aton Capital (ed.) (2006f): Evraz Group - Millhouse sees Evraz as platform for the Russian steel industry consolidation, September 8, http://www.aton.ru.

BEE (ed.) (2006): A rising trajectory: Foreign direct investment into Russia will continue to grow rapidly despite regulatory uncertainty, Business Eastern Europe, June 5.

Bevan, Alan A./Estrin, Saul (2000): The Determinants of Foreign Direct Investment in Transition Economies, William Davidson Institute Working Papers, No. 342, October.

Black, B. (2001): The corporate governance behavior and market value of Russian firms, in: Emerging Markets Review, 2, 89-108.

BOFIT (ed.) (2006a): Aircraft builders consolidate into new giant, Bank of Finland Institute for Economies in Transition, BOFIT Weekly, September 1, http://www.bof.fi/bofit.

BOFIT (ed.) (2006b): Three-way merger in aluminium sector underway, Bank of Finland Institute for Economies in Transition, BOFIT Weekly, September 1, http://www.bof.fi/bofit.

EBRD (ed.) (1996): Transition report: Infrastructure and savings, http://www.ebrd.com/.

EBRD (ed.) (1997): Transition report: Enterprise performance and growth, http://www.ebrd.com/.

EBRD (ed.) (1998): Transition report: Financial sector in transition, http://www.ebrd.com/.

EBRD (ed.) (2004): Transition report: Infrastructure, http://www.ebrd.com/. 
EBRD (ed.) (2005): Transition report: Business in transition, http://www.ebrd.com/.

EIU (ed.) (2006): Russia: Country Report, June 2006, Economist Intelligence Unit, http://www.eiu.com.

EJC (ed.) (2006): The Russian Media Landscape, European Journalism Centre, http://www.ejc.nl/.

Filatotchev, I./Wright, M./Uhlenbruck, K./Tihanyi, L./Hoskisson, R.E. (2003): Governance, organizational capabilities, and restructuring in transition economies, in: Journal of World Business, 38, 4, 331-347.

Guriev, S./Rachinsky, A. (2004): Ownership concentration in Russian industry, Background paper for Russia CEM 2003.

Guriev, S./Lazareva, O./Rachinsky, A./Tsukhlo, S. (2004): Corporate governance in Russian industry, in: Problems of Economic Transition, 47, 3, 6-83.

Interfax (2006): Govt again postpones law restricting foreigners, March 7, http://www.interfax.com.

Jensen, N. (2002): Economic reform, state capture, and international investment in the transition economies, in: Journal of International Development, 14, 7, 973-977.

Korchagina Valeria (2006): In a Siberian Wasteland, Russian Oligarch Roman Abramovich Recreates a City of Flying Dogs, The St. Petersburg Times, September 5, http://www.sptimes.ru.

Kuznetsov, P./Murav'ev, A. (2001): State holding companies as a mechanism for managing enterprises in the state sector, in: Problems of Economic Transition, 44, 4, 49-69.

Kuznetsova, O./Kuznetsov, A. (1999): The State as a shareholder: responsibilities, and objectives, in: Europe-Asia Studies, 51, 3, 433-445.

Liuhto, K. (1999a): Learning New Productivity Criteria in Transition Economies - Evidence from 450 CIS Companies, ESRC Working Paper Series 141, University of Cambridge.

Liuhto, K. (1999b): The Transformation of the Soviet Enterprise and Its Management - A Literature Review, ESRC Working Paper Series 146, University of Cambridge.

Liuhto K. (2002): Russian Oil and Gas - A Source of Integration, Lappeenranta University of Technology.

McCarthy, D.J./Puffer, S.M. (2003): Corporate governance in Russia: a framework for analysis, in: Journal of World Business, 38, 397-415.

Moscow News (2006): Vladimir Putin's State-of-the-Nation Address, May 11, http://www.mosnews.com.

Moscow Times (2005): State Managers Take Over AvtoVAZ, December 23, http://www.themoscowtimes.com.

Moscow Times (2006a): Chemezov Says State Set to Take Over Titanium Makes, July 19, http://www.themoscowtimes.com.

Moscow Times (2006b): RusAl Seen as Next BHP Billiton, August 31, http://www.themoscowtimes.com.

Moskovskie Novosti (2004): Gosudarstvo eto sovet direktorov, June 4, http://www.mn.ru. 
Murav'ev, A. (2003): Federal State shareholdings in Russian companies, in: Problems of Economic Transition, 46, 8, 66-95.

Perotti, E.C./van Oijen, P. (2001): Privatization, political risk and stock market development in emerging economies, in: Journal of International Money and Finance, 20, 1, 43-69.

Puffer, S.M./McCarthy, D.J. (2003): The emergence of corporate governance in Russia, in: Journal of World Business, 38, 284-298.

RIA Novosti (2006a): Putin highlights strategic forces in state of the nation, May 10, http://en.rian.ru/.

RIA Novosti (2006b): Strategic-sector foreign investment law may be adopted in 2006, June 14, http://en.rian.ru/.

Russian Central Bank (ed.) (2006): http://www.cbr.ru/.

Satrom R./Zhdanov D. (2006): Foreign Investment in Russia: Reform and Re-Regulation, American Chamber of Commerce, http://www.amcham.ru.

Shekshnia, S.V. (2004): Roles, responsibilities, and independence of boards of directors, in: McCarthy, D.J./Puffer, S.M./Shekshnia, S.V. (ed.): Corporate governance in Russia, Cheltenham, UK: Edward Elgar.

Transport Strategy (2005): The Transport Strategy of the Russian Federation till 2020, http://www.government.ru.

Troika Dialog (ed.) (2006a): Bar lowered for 'strategic' oil and gas fields, June 14, http://www.troika.ru.

Troika Dialog (ed.) (2006b): Natural Resources Ministry to add 70 fields to 'strategic' head count, June 20, http://www.troika.ru.

Troika Dialog (ed.) (2006c): Alfa Group CEO meets with Putin, August 11, http://www.troika.ru.

Troika Dialog (ed.) (2006d): Gref: Svyazinvest will not be sold at all, August 16, http://www.troika.ru.

Troika Dialog (ed.) (2006e): Liberalization: Fiat Lux, Troika Dialog Research Corporate Governance, http://www.troika.ru.

Vahtra P./Liuhto K. (2004): Expansion or Exodus - Foreign Operations of Russia's Largest Corporations, Pan-European Institute, http://www.tse.fi/pei/e.

Vedomosti (2004): Aktsionery MRK prismotyat za Svyazinvestom, February 16, http://www.vedomosti.ru. 